\title{
A Educação Ambiental como Proposta Interdisciplinar para Estudantes do Ensino Médio em uma Escola da Rede Pública Estadual de Manaus-AM
}

\author{
Environmental Education as an Interdisciplinary Proposal for High School Students in a Public \\ School of the Manaus-AM \\ La Educación Ambiental como Propuesta Interdisciplinar para Estudiantes do Ensino Medio en \\ una Escuela da Rede Publica Estadual de Manaus-AM
}

\author{
José Igor Pastor da Costa \\ ORCID: https://orcid.org/0000-0002-4653-9349 \\ Universidade do Estado do Amazonas, Brasil \\ E-mail: igorpastor.20@gmail.com \\ Aldalúcia Macêdo dos Santos Gomes \\ ORCID: https://orcid.org/0000-0002-1932-4350 \\ Universidade do Estado do Amazonas, Brasil \\ E-mail: aldalucia.gomes@gmail.com \\ Jaqueline Soares da Silva Ferreira \\ ORCID: https://orcid.org/0000-0002-8481-7581 \\ Universidade do Estado do Amazonas, Brasil \\ E-mail: contatosjsferreira@gmail.com \\ Janderson da Costa Barroso \\ ORCID: https://orcid.org/0000-0002-0308-7047 \\ Faculdade Tecnológica de Curitiba, Brasil \\ E-mail: janderbio2018@gmail.com \\ Paulo Alexandre de Lima Santiago \\ ORCID: https://orcid.org/0000-0002-1940-7447 \\ Universidade do Estado do Amazonas, Brasil \\ E-mail: psantiago@uea.edu.br \\ Sarah Raquel Silveira da Silva Santiago \\ ORCID: https://orcid.org/0000-0002-6943-8436 \\ Universidade do Estado do Amazonas, Brasil \\ E-mail: srhraquel@hotmail.com
}

\begin{abstract}
Resumo
Este texto apresenta resultados de uma pesquisa qualitativa oriunda de um projeto de intervenção realizado no decorrer da disciplina de Estágio Supervisionado do curso em Licenciatura em Ciências Biológicas da Universidade Federal do Amazonas, e desenvolvida com o principal objetivo de investigar a concepção dos sujeitos participantes da pesquisa acerca dos conceitos de Educação Ambiental e Interdisciplinaridade. A intervenção ocorreu no $1^{\circ}$ ano do Ensino Médio e contou com a colaboração voluntária de 31 estudantes do turno matutino. Para atingir o objetivo proposto, além da aplicação de questionários, os pesquisadores utilizaram-se da observação participante. A aplicação do questionário como instrumento de coleta de dados ocorreu em dois momentos: no início da intervenção, com o intuito de sondar os conhecimentos prévios dos estudantes e ao final, para verificar os possíveis conhecimentos apreendidos pelos estudantes. Ademais, realizou-se como estratégia didática: rodas de conversa, palestras com a temática "Reciclagem e Reutilização", e por fim uma oficina que oportunizou aos estudantes colocarem em prática alguns conhecimentos teóricos, bem como tirar dúvidas e até mesmo formular novos questionamentos. Os resultados apontaram que os participantes da pesquisa demonstraram interesse em tornar as ações vivenciadas no processo de intervenção em um projeto com atuações efetivas e por intermédio de atitudes interdisciplinares alcançar o máximo de adeptos entre o corpo discente, docente e administrativo da escola.
\end{abstract}

Palavras-chave: Educação ambiental; Sustentabilidade; Interdisciplinaridade; Reciclagem; Reutilização.

\section{Abstract}

This text presents the results of a qualitative research coming from an intervention project carried out during the Supervised Internship course of Biological Sciences Degree at the Federal University of Amazonas, and developed with the main objective of investigating the conception of the participating subjects in the research about their concepts in Environmental Education and Interdisciplinarity. The intervention took place in the 1st year of high school and had the voluntary collaboration of 31 students from the morning shift. To achieve the proposed objective, in 
addition to the application of questionnaire, the researches used participant observation. The questionnaire application as a data collection instrument took place in two phases: at the beginning of the intervention in order to probe the students' prior knowledge and at the end to verify the possible knowledge learned by the students. Furthermore, as a didactic strategy, conversation circles, lectures with the theme "Recycling and Reuse" were carried out, and finally a workshop that gave students the opportunity to put into practice some theoretical knowledge, as well as clarify any doubts and even formulate new questions. The results pointed out that the research participants showed interest in turning the actions experienced in the intervention process into a project with more effective actions and through interdisciplinary attitudes to reach the maximum number of followers among the student, teaching and administrative body of the school.

Keywords: Environmental education; Sustainability; Interdisciplinarity; Recycling; Reuse.

\section{Resumen}

Este texto presenta resultados de una pesquisa cualitativa oriunda de un proyecto de intervención realizado en el decorrer del Estagio Supervisionado del curso Licenciatura en Ciencias Biologicas de la Universidad Federal de Amazonas, y desarollada con el principal objetivo de investigar la concepción de los sujetos participantes acerca de los conceptos de la Educación Ambiental y Interdisciplinaridad. La intervención ocurrió en el $1^{\circ}$ año del Ensino Medio y contó con la colaboración voluntaria de 31 estudiantes del turno matutino. Para alcanzar el objetivo propuesto, además de la aplicación del cuestionario, los pesquisadores utilizaron la observación participante. La aplicación del cuestionario como instrumento de la colecta de datos fue realizada en dos momentos distintos: en el inicio de la intervención con el intuito de sondar los conocimientos previos de los estudiantes y al final, para verificar los posibles conocimientos aprendidos por ellos. Además, se realizaron como estratégias didácticas: ruedas de charlas, palestras con la temática "Reciclaje y Reutilización", y por fin un taller que dió la oportunidad a los estudiantes de poner en práctica algunos conocimientos teóricos como aclarar dudas y hasta formular nuevos cuestionamientos. Los resultados apuntaron que los participantes de la pesquisa demonstraron interés en tornar las acciones vivenciadas en el proceso de intervención no proyecto con actuaciónes efectivas y por medio de actitudes interdisciplinares alcanzar el máximo aptitudes entre el cuerpo discente, docente y administrativo de la escuela.

Palabras clave: Educación ambiental; Sostenibilidad; Interdisciplinaridad; Reciclaje; Reutilización.

\section{Introdução}

O Artigo 61 da Lei nº. 9.394/96, em seu parágrafo único, determina que a formação dos profissionais da Educação, de modo a atender às especificidades do exercício de suas atividades, bem como aos objetivos das diferentes etapas e modalidades da educação básica, terá como fundamentos: I) a presença de sólida formação básica, que propicie o conhecimento dos fundamentos científicos e sociais de suas competências de trabalho; II) a associação entre teorias e práticas, mediante estágios supervisionados e capacitação em serviço; III) o aproveitamento da formação e experiências anteriores, em instituições de ensino e em outras atividades (Senado Federal, 2020).

No curso de Licenciatura em Ciências Biológicas da Universidade Federal do Amazonas, o Estágio Supervisionado encontra-se organizado em 4 etapas, totalizando uma carga horária de 405 horas e estabelece como objetivos: I - proporcionar ao aluno uma relação interdisciplinar do conhecimento teórico com a prática vivenciada; II - elaborar um projeto de ensino para uma escola de Educação Básica ou instituição equivalente; III - capacitar o estagiário para o exercício da docência em todas as suas dimensões. Ademais, serão momentos essenciais de iniciação profissional, pois, além de continuar a aproximação e a integração do aluno com a realidade educacional, permitirá o conhecimento do campo de trabalho do professor de Biologia no Ensino Médio, constituindo-se como uma parte importante da formação pedagógica e, ao serem articulados às ações com o profissional da área, permitirão uma melhor orientação da prática educativa aos acadêmicos (Projeto Pedagógico do Curso de Licenciatura em Ciências Biológicas, 2012).

Durante a vivência dessa fase do processo de formação inicial de professores, os autores tiveram a possibilidade de elaborar, propor e executar um projeto de intervenção com estudantes do $1^{0}$ ano do Ensino Médio, do turno matutino, em uma escola estadual da rede pública de ensino, situada na região sul da cidade de Manaus, tendo como premissa a construção de pontes que possibilitassem o diálogo com os estudantes acerca da educação ambiental em uma perspectiva interdisciplinar. 
Percebeu-se que, embora o professor ministrante dos componentes curriculares de Biologia e Ciências demonstrasse um "olhar preocupado" com as questões ambientais, ainda assim, à medida que se consolidava a aproximação dos autores com o ambiente escolar, mais se evidenciavam as observações sinalizadas por parte de alguns estudantes em relação à utilização de grande quantidade de papel na escola, por vezes, de forma desnecessária e dispendiosa.

Tais observações despertaram inquietações que, com o estreitamento do convívio, evoluíram para dúvidas e questionamentos, e foi justamente a partir desse processo que foi possível a sistematização do seguinte problema de investigação: de que forma os termos reciclagem e reutilização de papel podem integrar um projeto de intervenção voltado para a educação ambiental sob a ótica da interdisciplinaridade? Desta pergunta originou-se o principal objetivo "investigar a concepção dos sujeitos participantes da pesquisa acerca dos conceitos de Educação Ambiental e Interdisciplinaridade"

Assumida como obrigação nacional na Constituição Federal de 1988, e assegurada pelo Estado nas três esferas do governo (Brasil, 1988), várias iniciativas foram implementadas para introduzir as temáticas ambientais nos currículos escolares no Brasil, ou seja, a inserção da educação ambiental nas escolas. Porém, muitos professores optam por não abordar essa temática em sala de aula, muitas vezes por considerar que esse tema não foi abordado durante a sua graduação ou na sua formação como um todo, o que de certa forma, gera insegurança e isso faz surgir uma carência muito grande de projetos relacionados à educação ambiental nas escolas (Farnesi, 1999).

Sorrentino e Trajber (2007), afirmam que no tocante ao âmbito internacional, entre os principais documentos firmados pelo Brasil, merece destaque o da Conferência Intergovernamental de Educação Ambiental de Tbilisi, capital da Geórgia (exUnião Soviética), em outubro de 1977. Sua organização ocorreu a partir de uma parceria entre a Organização das Nações Unidas para a Educação, a Ciência e a Cultura (UNESCO) e o Programa das Nações Unidas para o Meio Ambiente (PNUMA). Desse encontro saíram as definições, os objetivos, os princípios e as estratégias para a educação ambiental que até os dias atuais são adotados em todo o mundo.

Os autores supracitados sinalizam a existência de outros documentos internacionais que orientam as ações da educação ambiental, são eles, o Manifesto pela Vida e a Carta da Terra, que constituem a base de princípios para os processos da Agenda 21. Contudo, para o Ministério da Educação, tem extrema relevância o Tratado de Educação Ambiental para Sociedades Sustentáveis e Responsabilidade Global, elaborado pela sociedade civil planetária em 1992, durante a Conferência das Nações Unidas sobre o Meio Ambiente e Desenvolvimento (Rio-92). Loureiro (2012, como citado em Costa \& Loureiro, 2017), relembra a escolha, de forma consensual, do nome do educador brasileiro Paulo Freire para a realização da abertura da I Jornada Internacional de Educação Ambiental, evento de destaque na área, realizado durante a Rio-92, pois, embora Freire não tivesse se dedicado especificamente ao estudo da questão ambiental, mas em suas amplas reflexões presentes em sua obra, abrem possibilidades para refletirmos acerca das relações sociedade-natureza. Neste sentido, as contribuições de Paulo Freire a partir da perspectiva interdisciplinar convergiram para o debate da educação ambiental crítica.

Conforme supracitado, o Tratado de Educação Ambiental para Sociedades Sustentáveis e Responsabilidade Global, trata-se de um documento que afirma o caráter crítico, político e emancipatório da educação ambiental. Ele marca a mudança de acento do ideário desenvolvimentista para a noção de "sociedades sustentáveis", construídas a partir de princípios democráticos em modelos participativos de educação popular e gestão ambiental. Finalmente, as Nações Unidas e a UNESCO tiveram a iniciativa de implementar a Década da Educação para o Desenvolvimento Sustentável (2005-2014), cuja instituição representa um marco para a educação ambiental, pois reconhece seu papel no enfrentamento da problemática socioambiental à medida que reforça mundialmente a sustentabilidade a partir da Educação.

Oliveira e Silveira (2014), alertam para o importante processo de mudança do papel das escolas junto à comunidade. A escola deve ser colocada como um dos ambientes que poderá ser utilizado para disseminar a educação ambiental. Sendo essa educação capaz de formar cidadãos com consciência local e planetária. Contudo, alerta-se que tal "papel" não pode de forma 
alguma ficar sob a responsabilidade somente da escola, pois para que ocorra a disseminação da educação ambiental de forma efetiva e contínua, faz-se necessário o engajamento de todos, como família, sociedade e Estado, no sentido de contribuir com os estudantes e professores para que esse movimento, uma vez iniciado na escola ultrapasse os "muros" que a delimitam e possa expandir-se por toda a comunidade oportunizando melhores perspectivas de vida para todas as pessoas.

\section{Metodologia}

Os caminhos trilhados neste processo de investigação, vão ao encontro com o afirmado por Gomes e Ghedin (2013), que para a realização de uma pesquisa neste contexto exige o constante observar, pensar, questionar e refletir sobre meios que possam contribuir para a análise, compreensão e intervenção da realidade adentrada, neste caso, a escola. O estudo foi orientado pela pesquisa qualitativa por se acreditar que esta modalidade de pesquisa possibilita ao pesquisador um olhar mais humanista, holístico e aproximado da realidade dos sujeitos. Desta forma, a pesquisa qualitativa permite a interação entre o pesquisador com os sujeitos participantes do estudo facultando-lhe o direito de relatar de forma fidedigna, o que deu certo e o que deu errado, as fragilidades e fortalezas observadas no decorrer da pesquisa oportunizando a interlocução entre a teoria e os dados empíricos (Triviños, 2009).

O caminho trilhado durante a execução do projeto apoderou-se de contribuições da pedagogia da pesquisa-ação, que segundo Ghedin e Franco (2008, p. 212), "quando alguém opta por trabalhar com pesquisa-ação, decerto se investe da convicção de que pesquisa e ação podem e devem caminhar juntas, tendo em vista a transformação da prática. No entanto, a direção, o sentido e a intencionalidade dessa transformação serão o eixo caracterizador de tal abordagem".

No intuito de obter informações, realizou-se a aplicação de dois questionários - um anterior à intervenção (sondagem acerca dos conhecimentos prévios) e outro, posterior à intervenção (verificação de conhecimento apreendido) com perguntas semiestruturadas, pois permitem ao pesquisador partir de questões chave reelaborá-las de acordo com as respostas obtidas. Tal instrumento de coleta demonstrou-se fundamental à compreensão do fenômeno estudado (Lüdke \& André, 2003). De acordo com Triviños (2009, p. 146), esta técnica de coleta de informações possibilita "[...] o informante, seguindo espontaneamente a linha de seu pensamento e de suas experiências dentro do foco principal colocado pelo investigador, [...] participar na elaboração do conteúdo da pesquisa".

Ademais, realizou-se observação participante que, segundo Vianna (2003), é uma das mais importantes fontes de informações em pesquisas qualitativas em educação, neste tipo de observação o observador é parte dos eventos que estão sendo pesquisados. Esse tipo de observação apresenta algumas vantagens: i) possibilita a entrada a determinados acontecimentos que seriam privados e aos quais um observador estranho não teria acesso aos mesmos; ii) permite a observação não apenas de comportamentos, mas também de atitudes, opiniões, sentimentos, além de superar a problemática de efeito observador. Minayo (2013), complementa que a importância da observação participante é de tal ordem que alguns estudiosos a consideram não apenas uma estratégia no conjunto de investigação, mas também como um método que permite a compreensão da realidade adentrada.

Vale ressaltar que os autores, enquanto proponentes de um projeto a ser implementado na escola, não chegaram ao lócus da pesquisa com uma ideia pronta e acabada acerca do que dever ser proposto. A ideia, desde o início, constituiu-se em tentar diminuir o "abismo" estabelecido entre a Escola - que recebe os licenciandos - e a Universidade. Neste sentido, embora, não se soubesse exatamente o que propor havia a convicção de que tal proposta deveria ser pensada, discutida, desenvolvida e implementada em alinhamento com as reais necessidades dos contextos e ambientes de atuação daqueles que constituem a Escola. O tema/problema/problematização emergiram a partir das rodas de conversas com os estudantes.

Os momentos supracitados foram decisivos para que os autores pudessem captar algumas dúvidas, curiosidades e inquietações relacionados à temática ambiental. Ademais, ficou evidenciado na fala de alguns estudantes que gostariam de ver 
todos os professores envolvidos, pois causava "estranheza" a alguns o fato de observarem somente o professor de Ciências e Biologia trabalhando com a temática voltada para questões do meio ambiente. Embora, não soubessem explicar que seus anseios estavam de acordo com uma proposta interdisciplinar - pois alguns desconheciam o termo, outros tinham uma vaga ideia, mas não conseguiam organizar uma opinião do significado de interdisciplinaridade - ficou explícito em suas manifestações que já haviam compreendido que somente para um professor seria muito difícil promover alguma mudança ou transformação de forma efetiva e eficaz na escola, no tocante à temática ambiental.

O momento anterior vivenciado nas rodas de conversas apontou direcionamento para a realização da próxima etapa da pesquisa. Então, com o objetivo de captar os conhecimentos prévios dos estudantes acerca de termos relacionados ao processo de educação ambiental, bem como suas percepções sobre interdisciplinaridade, elaborou-se e aplicou-se um questionário, com sete perguntas abertas. São elas: 1) Você sabe o que é sustentabilidade? 2) O que você faz com o lixo que produz na escola? 3) Você sabe o que é coleta seletiva? 4) Você sabe separar corretamente o lixo para a reciclagem? 5) Você se preocupa com as questões ambientais? 6) Você sabe a diferença entre reciclar e reutilizar? 7) Qual o seu entendimento acerca do termo interdisciplinaridade?

Durante o processo de elaboração do questionário prévio, optou-se em trabalhar com perguntas abertas, haja vista a relevância de captar o máximo de informações dos estudantes, contudo, se por um lado essa escolha tenha proporcionado rica fonte de informações, por outro tornou-se mais complexa sua análise. Neste sentido, concorda-se com Gomes \& Ghedin (2013), ao afirmarem que o processo de análise se constitui em etapa muito difícil para os pesquisadores, pois nesse momento surgiram inseguranças sobre quais dados deveriam ser utilizados, o que realmente era importante constar no relatório de pesquisa e o que poderia ser descartado sem comprometer a qualidade das conclusões a que se chegariam. Essa dificuldade, de acordo com Lüdke e André (2003, como citado em Gomes \& Ghedin, 2013), decorre do exaustivo trabalho que configura uma pesquisa qualitativa, pois analisar dados qualitativos significa trabalhar todo o material (informações) obtido.

Após a aplicação, análise e categorização das informações obtidas a partir do questionário prévio, iniciou-se o processo de planejamento para a realização de uma "palestra interativa" que possibilitasse aos estudantes o aprofundamento de alguns conceitos, bem como fomentar estímulo nos estudantes, no sentido de buscarem mais conhecimento acerca das temáticas relacionadas à educação ambiental e interdisciplinaridade.

Após realização da "palestra interativa" e como forma de atender aos anseios e preocupações dos estudantes acerca do uso, por vezes inadequado do papel, bem como o interesse pela reciclagem e reutilização deste material, montou-se uma oficina no laboratório da escola. Sob orientação dos autores, os próprios estudantes encarregaram-se em realizar a coleta do papel. Organizados em equipes, foram à todas as salas de aula avisar professores e demais colegas que ao final das aulas passariam realizando a coleta do papel descartado nas lixeiras postas dentro das salas, orientaram ainda para que não misturassem lixo orgânico com o papel que seria coletado, pois este não poderia estar sujo.

Além das salas de aulas, foram também à secretaria, coordenação pedagógica, sala de professores e direção da escola. Alguns professores que lecionavam em outros turnos divulgaram em suas turmas o projeto dos estudantes do turno matutino, solicitando que contribuíssem mantendo o papel no formato adequado para o processo de reciclagem. Os funcionários responsáveis pela limpeza da escola também passaram a contribuir com o projeto separando o papel que poderia ser utilizado na oficina. $\mathrm{O}$ custo dos demais produtos utilizados na oficina de reciclagem ficaram sob responsabilidade dos autores. Após a conclusão da oficina de reciclagem, todo o papel reciclado foi utilizado pelos próprios estudantes na confecção de pequenos blocos de anotações - distribuídos aos professores, coordenadora pedagógica, gestora e funcionários da secretaria - utilizou-se ainda o papel reciclado durante as atividades práticas do componente curricular Arte, na confecção de painéis/desenhos, bem como em Biologia na elaboração de mapas mentais etc. 
Após a realização da oficina, solicitou-se aos estudantes que respondessem a um questionário composto por cinco perguntas que serviu como instrumento de avaliação final do projeto de intervenção, por meio do qual foi possível captar a percepção dos estudantes quanto às questões de reciclagem e reutilização de papel. São elas: 1) Após a "palestra interativa" e a oficina sobre reciclagem e reutilização do papel, como você avalia a reutilização do papel reciclado em sua escola? 2) A partir de hoje, como você descartaria o papel utilizado em sua escola? 3) Em sua opinião, quais são os benefícios da reciclagem e reutilização de papel em relação à sustentabilidade? 4) Para se ter um mundo mais sustentável, como você ajudaria a diminuir o desperdício de papel em seu cotidiano? 5) Você consegue relacionar a temática da educação ambiental com interdisciplinaridade?

\section{Resultados e Discussão}

Para obter os resultados do estudo realizou-se as rodas de conversas, palestras interativas, aplicacações de questionários pré e pós-intervenção, bem como as oficinas de reciclagem e reutilização do papel utilizado em todos os setores da escola. Ademais, procedeu-se revisão de literatura de textos relacionados à educação ambiental e interdisciplinaridade.

O momento de realização das palestras oportunizou aos estudantes o esclarecimento de dúvidas decorrentes da explanação das temáticas abordadas. Além de esclarecerem suas dúvidas, manifestaram preocupação com a grande quantidade de papel utilizada em todos os setores da escola, conseguiram ainda, compreender a relação direta do uso do papel com os Componentes Curriculares Biologia e Química, seja por sua origem vegetal ou por sua composição e processo de transformação química ao qual é submetido na indústria de celulose, até o catastrófico dano que o uso dispendioso desse material pode causar ao meio ambiente.

Na primeira fase, houve a participação de 31 estudantes do primeiro ano do Ensino Médio de uma Escola da Rede Pública de Ensino. A faixa etária predominante foi composta por estudantes entre 15 e 16 anos (96,7\%). O questionário prévio foi respondido por $100 \%$ dos participantes. Na questão um, perguntou-se aos participantes o que sabiam sobre sustentabilidade. Nas respostas, 14 estudantes (45\%) têm a ideia de que sustentabilidade é o uso racional e consciente dos recursos ambientais; 2 estudantes (6\%) responderam que sustentabilidade é quando "se tem um mundo mais limpo"; 11 estudantes (36\%) responderam que sustentabilidade são práticas que não prejudicam o meio ambiente; 4 estudantes (13\%) não souberam responder, conforme evidenciado na Figura 1.

Figura 1. Representação gráfica das respostas dos estudantes relacionada a sustentabilidade.

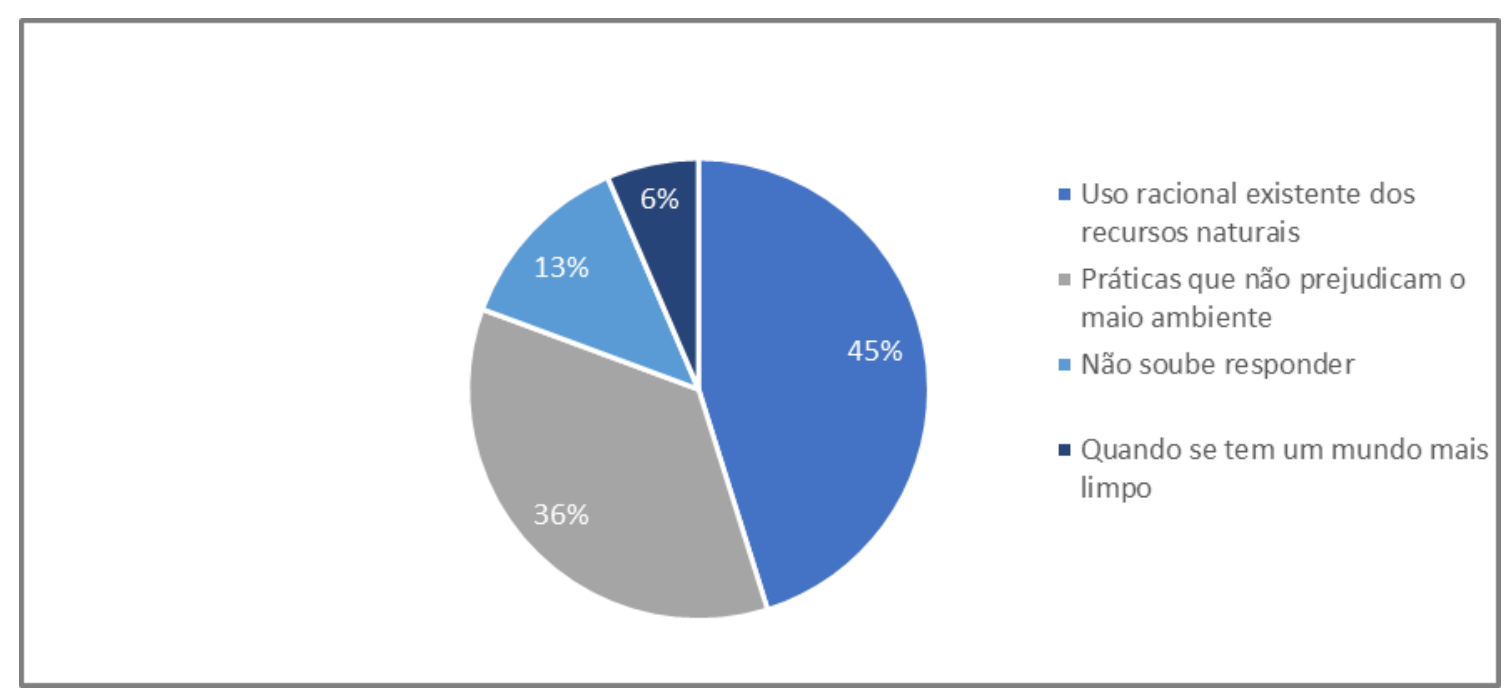

Fonte: Autores (2021). 
O gráfico acima demonstra que a maioria dos estudantes apresenta certa compreensão acerca de sustentabilidade. Acredita-se que o desenvolvimento de atividades voltados para a temática ambiental pode contribuir para que os estudantes consolidem e aprimorem seus conhecimentos, oportunizando a tomada de consciência de sua realidade de forma crítica, assegurando-lhe formação indispensável para o exercício da cidadania. Assim, ao longo da vida, a educação deve basear-se nos pilares: aprender a conhecer, aprender a fazer, aprender a viver juntos, aprender a ser. A educação deve tornar-se assim, uma construção contínua de cada pessoa humana, do seu saber de suas aptidões, de sua capacidade de discernir e agir (Miranda, Miranda \& Ravaglia, 2010).

Na segunda questão, indagou-se sobre o destino dado ao lixo produzido por eles na escola. Como resposta, obteve-se, 22 estudantes (73\%) responderam que jogam no lixo comum; 5 estudantes (17\%) disseram que selecionam o lixo e procuram lixeiras de coleta seletiva; 1 estudante (3\%) respondeu que não se preocupa e joga o lixo em qualquer lugar da escola; 2 estudantes (7\%) responderam que guardam o lixo para, posteriormente, jogá-lo em uma lixeira, de acordo com a Figura 2.

Figura 2. Representação gráfica das respostas dos estudantes em relação ao destino dado ao lixo produzido na escola.

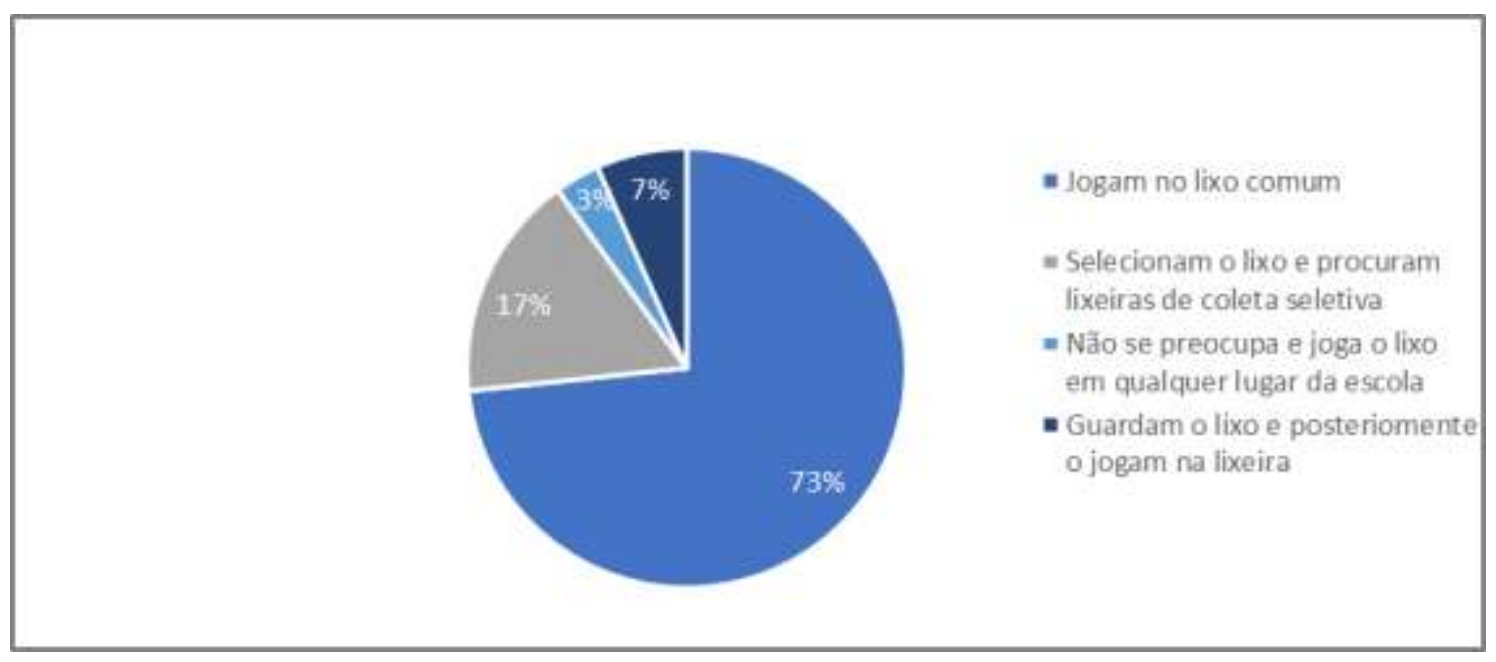

Fonte: Autores (2021).

Os dados do gráfico acima chamam a atenção para o fato de a maior parte dos estudantes, mesmo possuindo algum esclarecimento sobre questões ambientais, ainda assim, na hora de descartar seu lixo não o fazem de forma correta, uma vez que a escola possui coletores/lixeiras coletivas espalhadas em diversos pontos. Logo, torna-se urgente a adoção da educação ambiental como um processo de formação e informação que promova o desenvolvimento da consciência crítica das pessoas em relação aos problemas ambientais e as leva à percepção da necessidade de participar e fiscalizar as condições ambientais como um agente ativo. A Lei n ${ }^{\circ}$ 9.795, de 27 de abril de 1999, estabelece a necessidade de implantar no país a prática da educação ambiental como um componente necessário e permanente da educação nacional, para todos os níveis e modalidades do processo educativo, seja de modo formal ou não-formal. Contudo, espera-se que a educação ambiental não seja retratada como só mais um componente curricular, mas sim como prática educativa integrada e que seja incluída nos mais diversos temas abordados com os estudantes (Tavares, Sousa \& Santos, 2018).

$\mathrm{Na}$ terceira questão, indagou-se aos estudantes se sabiam o que era coleta seletiva. As respostas foram, 27 estudantes (87\%) responderam que sim, sabiam o que era coleta seletiva; 4 estudantes (13\%) responderam que não sabiam o que era coleta seletiva, conforme evidenciado na Figura 3. 
Figura 3. Representação gráfica das respostas dos estudantes em relação à coleta seletiva.

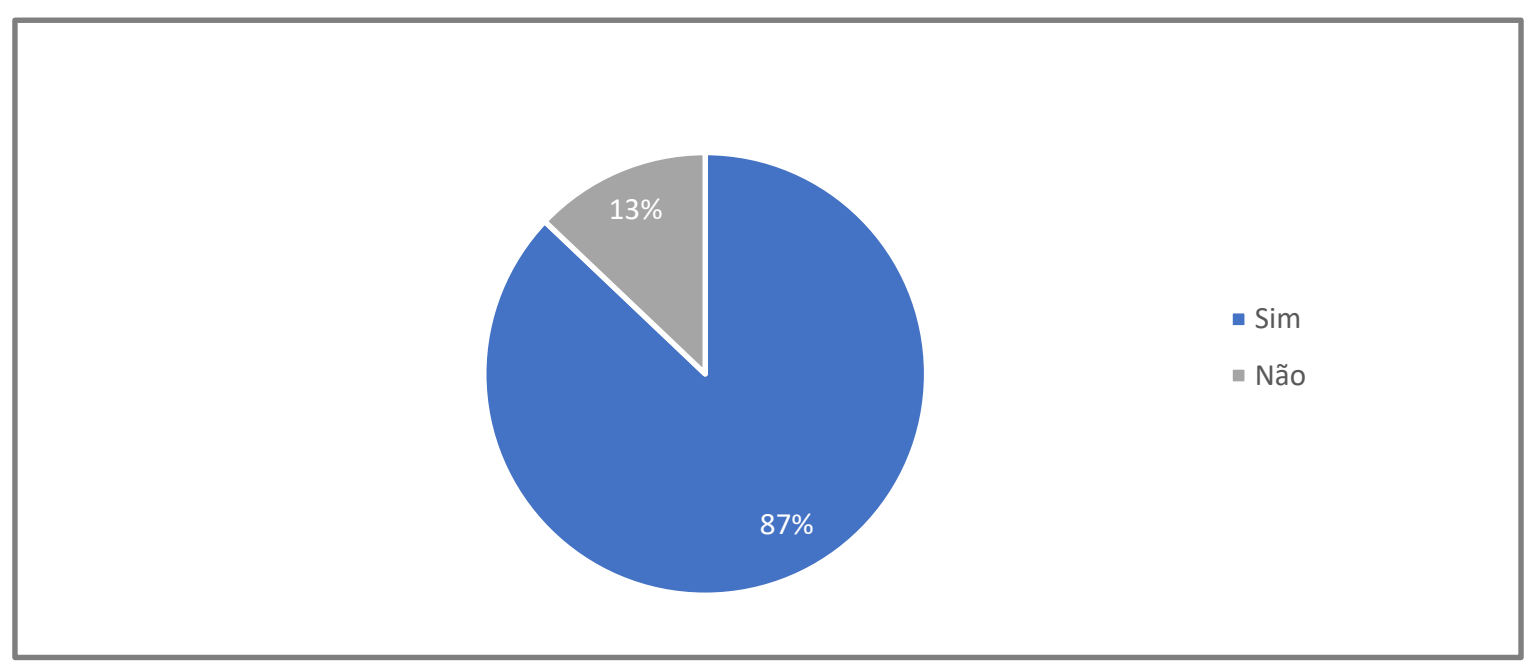

Fonte: Autores (2021).

Ao se comparar os dados do Gráfico 3 com os apresentados no 2, percebeu-se que, embora a maioria dos estudantes saiba o significado de coleta seletiva, observa-se que tal conhecimento acaba ficando mais no campo teórico, uma vez que a maioria dos estudantes respondeu na pergunta anterior que descartavam o lixo produzido por eles em lixeiras comuns. Em relação a isso Souza et al., (2013), afirmam que comportamentos ambientalmente corretos devem ser aprendidos na prática e a escola, pode contribuir significativamente para esse processo através da formação de sujeitos críticos e reflexivos capazes de atuar na complexa realidade socioambiental, contemplando sua pluralidade de aspectos.

A pergunta quatro indagou aos participantes se sabiam separar corretamente o lixo para reciclagem. Como respostas, 26 estudantes (84\%) responderam que sabiam separar corretamente o lixo para reciclagem; 5 estudantes (16\%) responderam que não sabiam separar o lixo corretamente, de acordo com a Figura 4.

Figura 4. Representação gráfica das respostas dos estudantes em relação à separação correta do lixo para reciclagem.

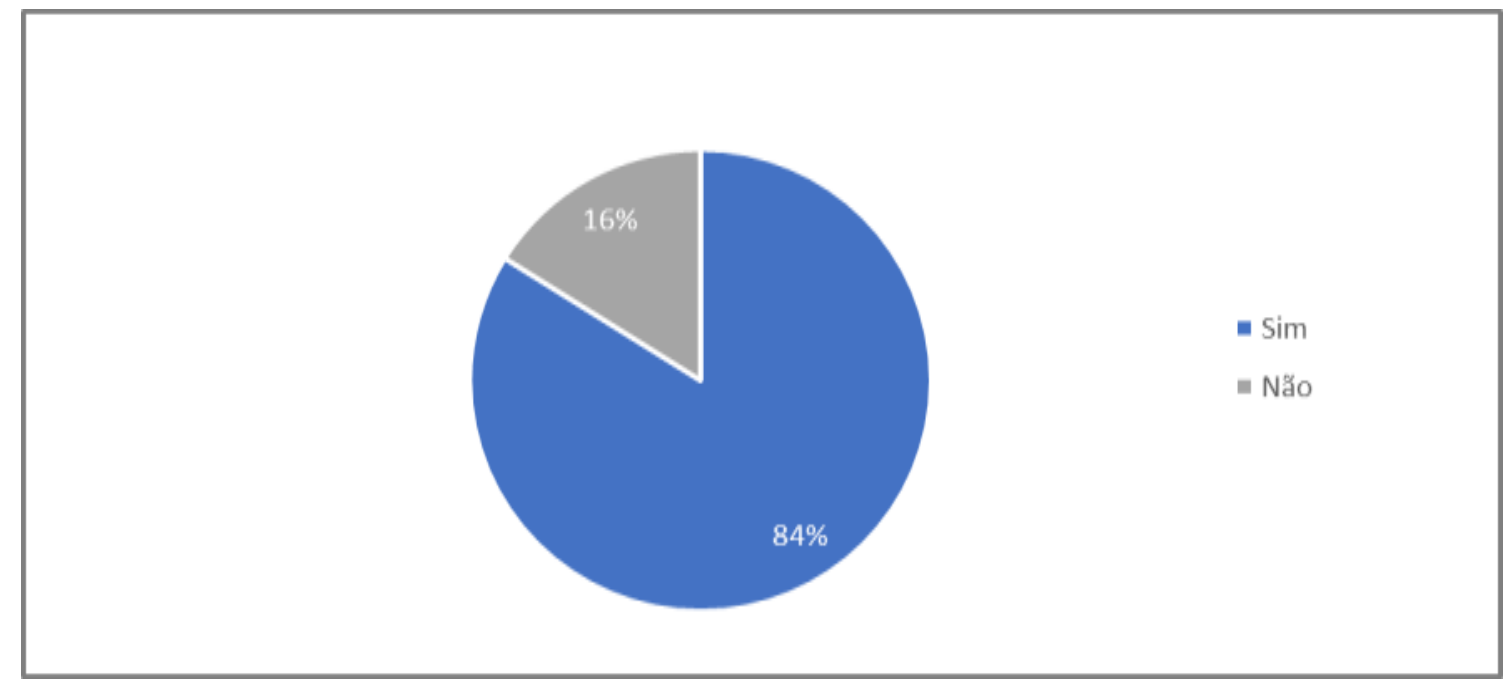

Fonte: Autores (2021).

Ao proceder a análise das respostas da questão quatro representadas no gráfico acima, mais uma vez foi motivo de preocupação para os autores deste estudo, pois ficou evidente a dificuldade na articulação entre o que os estudantes sabem (teoria) e o que eles praticam em seu cotidiano, ora se um dos principais objetivos da educação ambiental é promover a 
transformação social é necessário que a teoria dialogue com a prática. Contudo, esse diálogo visando a transformação social não pode ficar restrito ao ambiente escolar, mas em todos os espaços da sociedade podendo ocorrer de maneira individual e coletiva com o propósito de formar cidadãos com consciência que sejam capazes de se importar com os problemas globais, mas sem descuidar dos problemas locais observando suas causas e inter-relações em uma perspectiva sistêmica, em seus contextos sociais e históricos (Tavares, Sousa \& Santos, 2018).

Considera-se que indivíduos sensibilizados e conscientizados sentem e compreendem os problemas e desafios ambientais e, portanto, têm mais condições de agir de forma contínua e permanente e eficaz. Agir construindo planos de ação e soluções que serão depois implementados e avaliados. Cabe destacar que somente quem sente a necessidade de mudar estará aberto a compreender racionalmente os desafios ambientais e disposto a agir para mudar (Oliveira \& Silveira, 2014).

A questão cinco indagou aos estudantes se eles se preocupavam com as questões ambientais, de acordo com as respostas, 28 estudantes (90\%) responderam que sim, se preocupam com as questões ambientais; 3 estudantes (10\%) informaram que não se preocupavam com as questões ambientais, conforme apresentadas na Figura 5.

Figura 5. Representação gráfica das respostas dos estudantes relacionadas às questões ambientais.

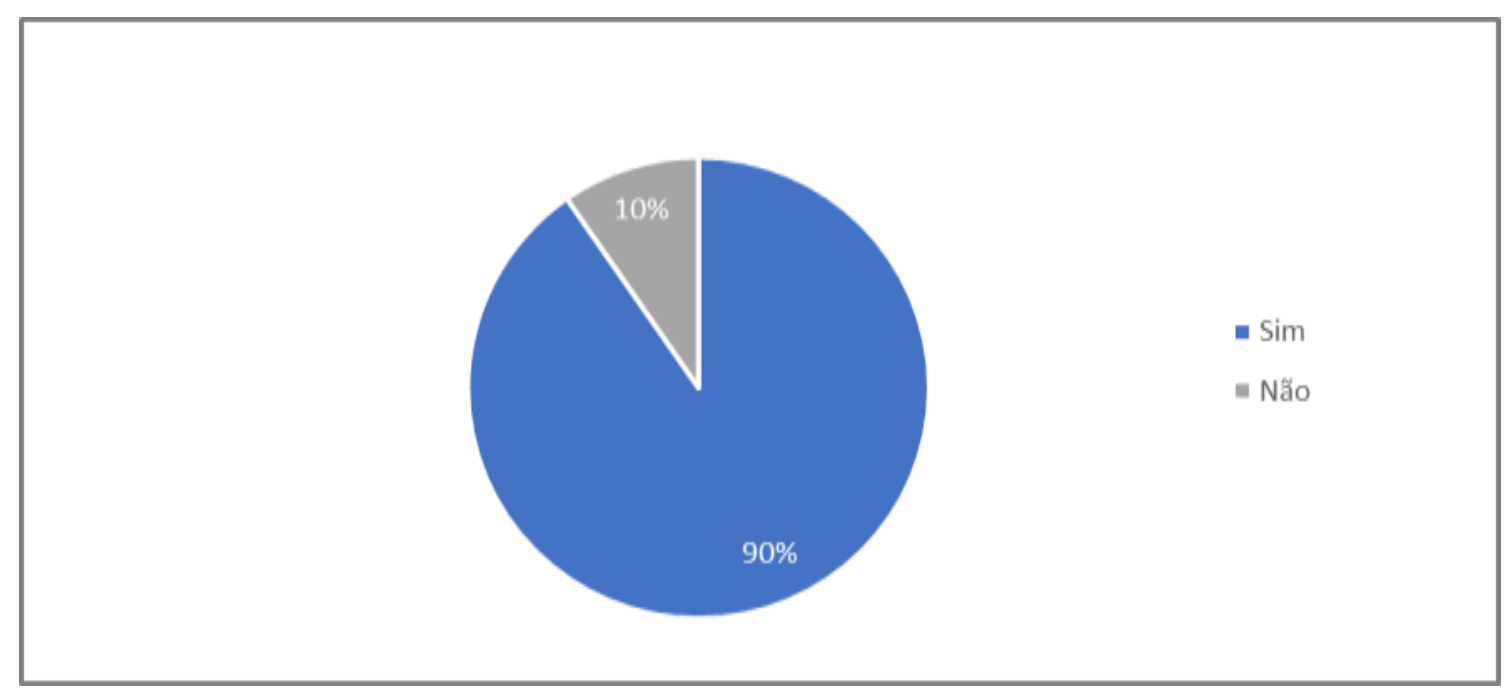

Fonte: Autores (2021).

Os resultados apresentados no gráfico acima refletem muito a "fala" dos estudantes durante as rodas de conversas, pois alguns deles manifestaram preocupação em relação às questões ambientais, principalmente, em âmbito nacional, pois segundo suas observações, apesar de o Brasil ter vários biomas e consequentemente rica diversidade em fauna e flora sabem que essas fontes naturais não são inesgotáveis e temem que a falta de fiscalização ambiental contribua para um rápido processo de degradação do meio ambiente. A preocupação dos estudantes vai ao encontro a afirmação de Rossini e Cenci, (2020), de que no Brasil, os problemas ambientais mais graves relacionam-se ao desmatamento, aos incêndios florestais, à erosão, à escassez de água, à desertificação, à extinção de espécies, ao aumento de favelas, ao uso inadequado da terra, bem como, à exploração dos recursos naturais por processos predatórios que atendem exclusivamente aos interesses de uma pequena parte da população.

A sexta pergunta do questionário procurou saber se os estudantes sabiam a diferença entre reciclar e reutilizar. Como respostas obtive-se, 26 estudantes (84\%) responderam que sabiam a diferença entre reciclar e reutilizar; 5 estudantes (16\%) disseram que não sabiam a diferença entre reciclar e reutilizar, de acordo com a Figura 6. 
Figura 6. Representação gráfica das respostas dos estudantes acerca da diferença entre reciclar e reutilizar.

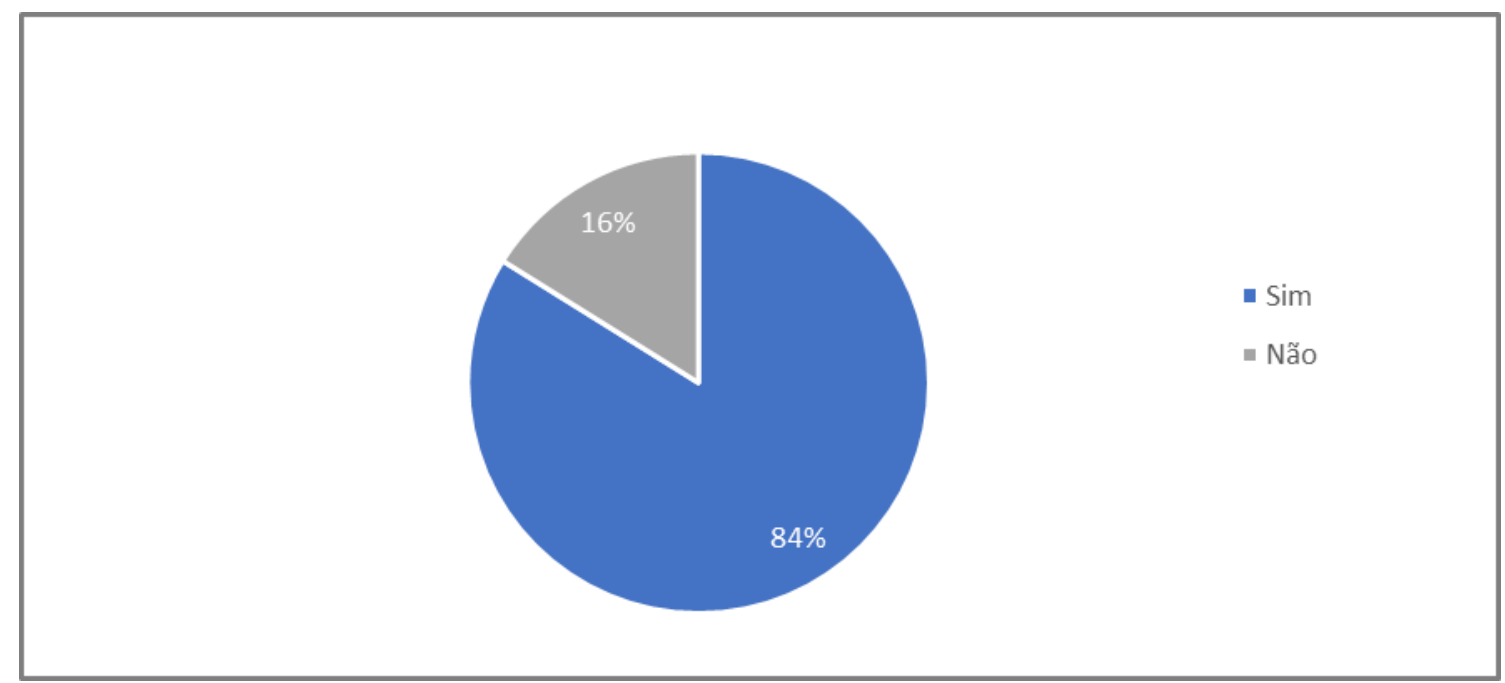

Fonte: Autores (2021).

O processo de análise das respostas apresentadas no gráfico acima remeteu-nos à preocupação manifestada por alguns estudantes, bem como às inúmeras indagações relacionadas ao grande consumo de produtos e o pouco investimento em processos de reciclagem ou reutilização de materiais como papel, embalagens plásticas etc. Neste sentido, Silva et al., (2014) afirmam que o acúmulo dos resíduos sólidos nos centros urbanos constitui-se em graves problemas de poluição e encontra-se baseado na tríade: consumo, recurso e resíduo, ou seja, o crescimento exponencial do consumo incentivado, principalmente, pela mídia, tem demandado o aumento considerado da utilização dos recursos naturais que por sua vez acarreta maior descarte de resíduos. Os autores citados anteriormente, enfatizam que diante deste cenário, a educação ambiental apresenta-se como importante instrumento de sensibilização e conscientização das pessoas, uma vez que pode ajudá-las a rever suas práticas de consumo, bem como, a utilização dos recursos naturais de forma responsável.

Na questão sete, indagou-se aos participantes acerca de seu entendimento sobre o termo interdisciplinaridade. Nas respostas, 36\% dos estudantes sabem do que se trata; 14 estudantes (48\%) já ouviram falar, mas não sabem explicar; 12 estudantes (39\%) compreendem, mas não sabem explicar; 5 estudantes (16\%) nunca ouviram falar, vide Figura 7.

Figura 7. Representação gráfica das respostas sobre o termo interdisciplinaridade.

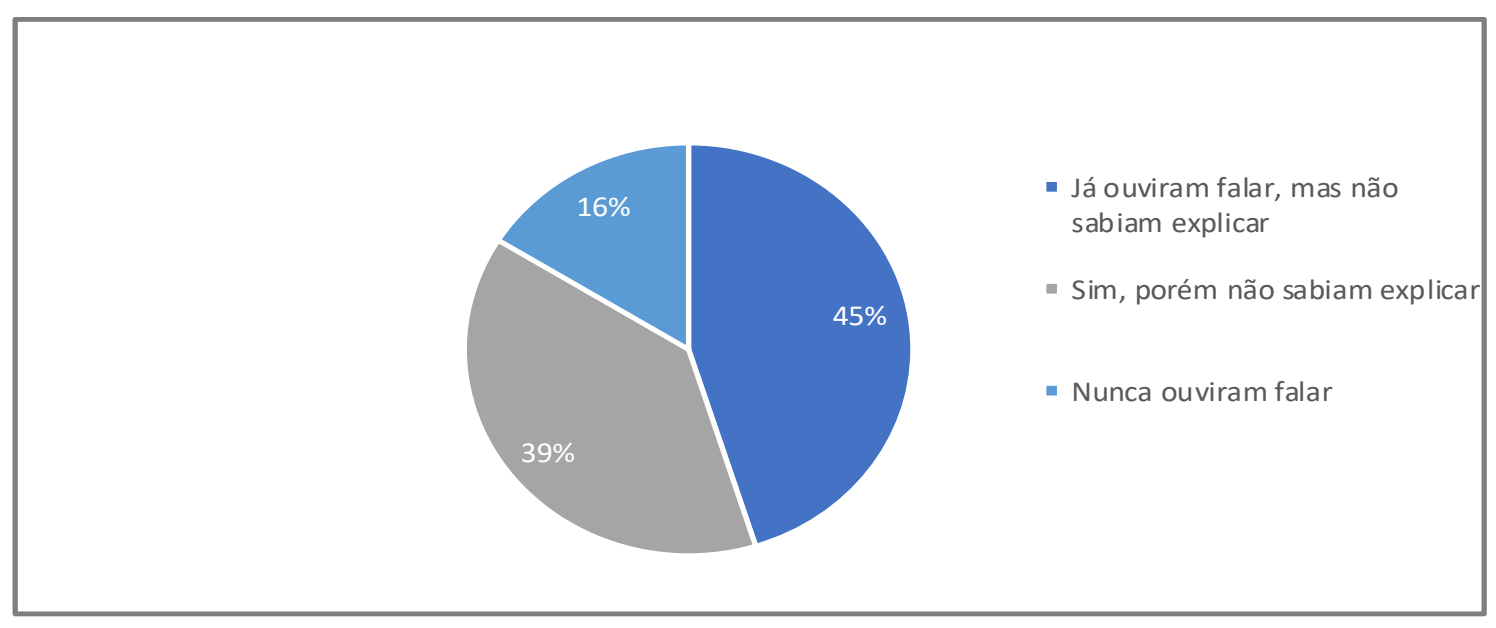

Fonte: Autores (2021). 
As respostas dos estudantes apresentadas no gráfico anterior retratam "suas falas" durante as rodas de conversa e na "palestra interativa", pois ficou evidenciado que consideravam as questões relacionadas ao meio ambiente como algo importante a ser trabalhado na escola, contudo, lhes causava estranheza tal trabalho estar sempre sob responsabilidade do Professor de Ciências e Biologia, não compreendiam o motivo pelo qual os demais professores não abordavam o tema em suas aulas. Percebeu-se ainda, em "suas falas" a necessidade de ver temas relacionadas ao meio sendo abordados nas demais disciplinas, ou seja, embora não conseguissem explicar o conceito de interdisciplinaridade, ainda assim, deixaram claro a necessidade de trabalhar a educação ambiental na perspectiva interdisciplinar. Considerando-se que um dos grandes desafios da educação ambiental é sua a inserção na educação formal sob ótica interdisciplinar em consonância com as diretrizes da Política Nacional de Educação Ambiental (Lei 9796/99, como superar esse desafio?

Pensar a interdisciplinaridade enquanto processo de integração recíproca entre as várias disciplinas e campos de conhecimento é sem dúvida, uma tarefa que demanda, de nossa parte, um grande esforço no rompimento de uma série de obstáculos ligados a uma racionalidade extremamente positivista da sociedade industrializada. Cabe-nos voltar para uma visão integrada do meio em que vivemos. A conferência Intergovernamental sobre Educação Ambiental de Tbilisi propôs como um dos princípios básicos aplicar um enfoque interdisciplinar, aproveitando o conteúdo específico de cada disciplina, de modo que se adquira uma perspectiva global e equilibrada. Para tentar colocar em prática as recomendações da Conferência, o Brasil aprovou e sancionou a lei supracitada estabelecendo a educação ambiental como um componente essencial e permanente da educação nacional, devendo estar presente de forma articulada, em todos os níveis e modalidades do processo educativo que deverá ser desenvolvida como uma prática educativa integrada, contínua e envolvendo todos os professores e não somente o professor dos componentes curriculares de Ciências e Biologia (Miranda, Miranda \& Ravaglia, 2010)

Ao final do projeto de intervenção, aplicou-se um questionário com o objetivo de verificar os conhecimentos apreendidos pelos estudantes acerca dos temas abordados desde as rodas de conversas até às oficinas de reciclagem e reutilização. Porém, no dia da aplicação do questionário final apenas 28 alunos estavam presentes na sala de aula. A primeira questão indagou aos estudantes: após as rodas de conversas, "palestra interativa", e a oficina realizada no laboratório sobre reciclagem e reutilização de papel, como você avalia o processo de se reutilização do papel reciclado em sua escola? Nas respostas, 14 estudantes $(50 \%)$ responderam que reciclar e reutilizar o papel contribuiria para diminuir o seu desperdício; 7 estudantes (25\%) responderam que reciclar e reutilizar o papel descartado nas lixeiras da escola diminuiria gastos financeiros compra de papel novo; 4 estudantes (14\%) responderam que a reciclagem e reutilização do papel deveria se tornar um projeto contínuo na escola; 3 estudantes (11\%) responderam que não perceberam importância alguma em reciclar e reutilizar o papel desperdiçado na escola, conforme a Figura 8. 
Figura 8. Representação gráfica da avaliação dos estudantes em relação à reutilização do papel reciclado em sua escola.

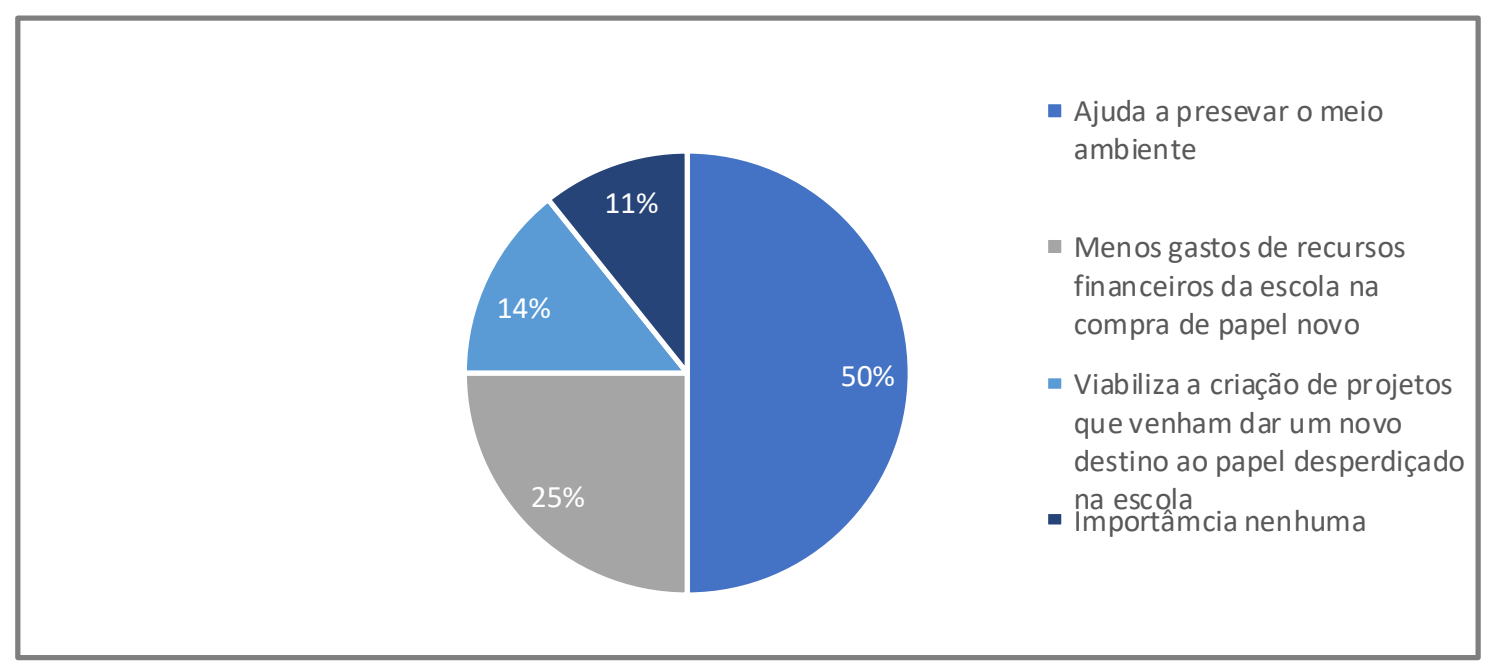

Fonte: Autores (2021).

A nona questão indagou aos estudantes: como deveria ser o descarte correto do papel utilizado na escola? Nas respostas, 17 estudantes $(61 \%)$ responderam que deveria ser em coletores apropriados para que pudessem ser utilizados na reciclagem e reutilização; 7 estudantes (25\%) responderam que o papel utilizado na escola deveria ser vendido para empresas especializadas em reciclagem; 3 estudantes (11\%) responderam que o papel deveria ser armazenado em um depósito para posteriormente ser doado para cooperativas de catadores de materiais recicláveis; 1 estudante (3\%) não soube responder, como evidenciado na Figura 9.

Figura 9. Representação gráfica das respostas dos participantes quanto ao descarte correto do papel utilizado na escola.

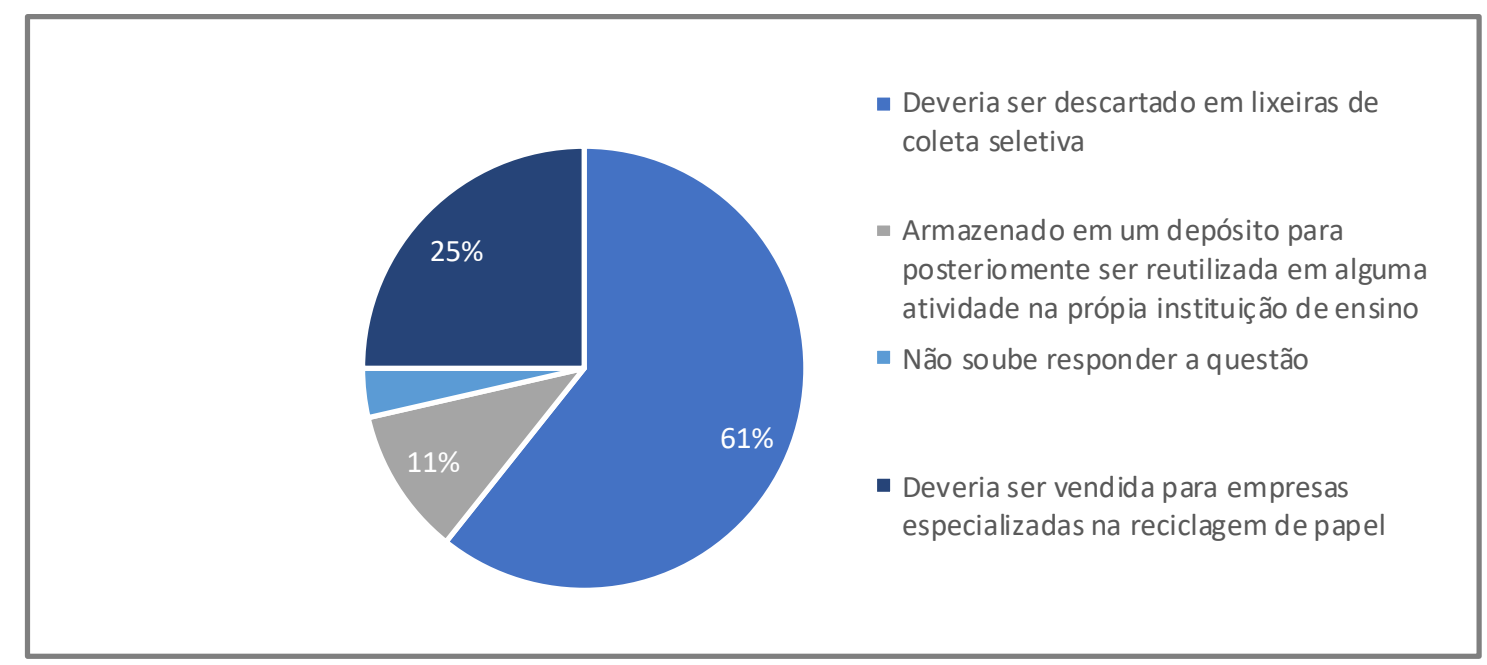

Fonte: Autores (2021).

Na décima questão, perguntou-se aos estudantes: se perceberam relação entre os benefícios da reciclagem e reutilização de papel com a sustentabilidade ambiental, justificando sua resposta. Nas respostas, 11 estudantes (39\%) responderam que sim, pois poderia diminuir o uso de matéria prima na produção de novos papéis; 8 estudantes (29\%) responderam que sim e com isso diminuiria a emissão de dióxido de carbono na atmosfera; 9 estudantes (32\%) responderam que sim, e que tal atitude diminuiria a poluição nas grandes cidades, como demonstra a Figura 10. 
Figura 10. Representação gráfica das respostas dos estudantes acerca da relação entre os benefícios da reciclagem e reutilização do papel e a sustentabilidade ambiental.

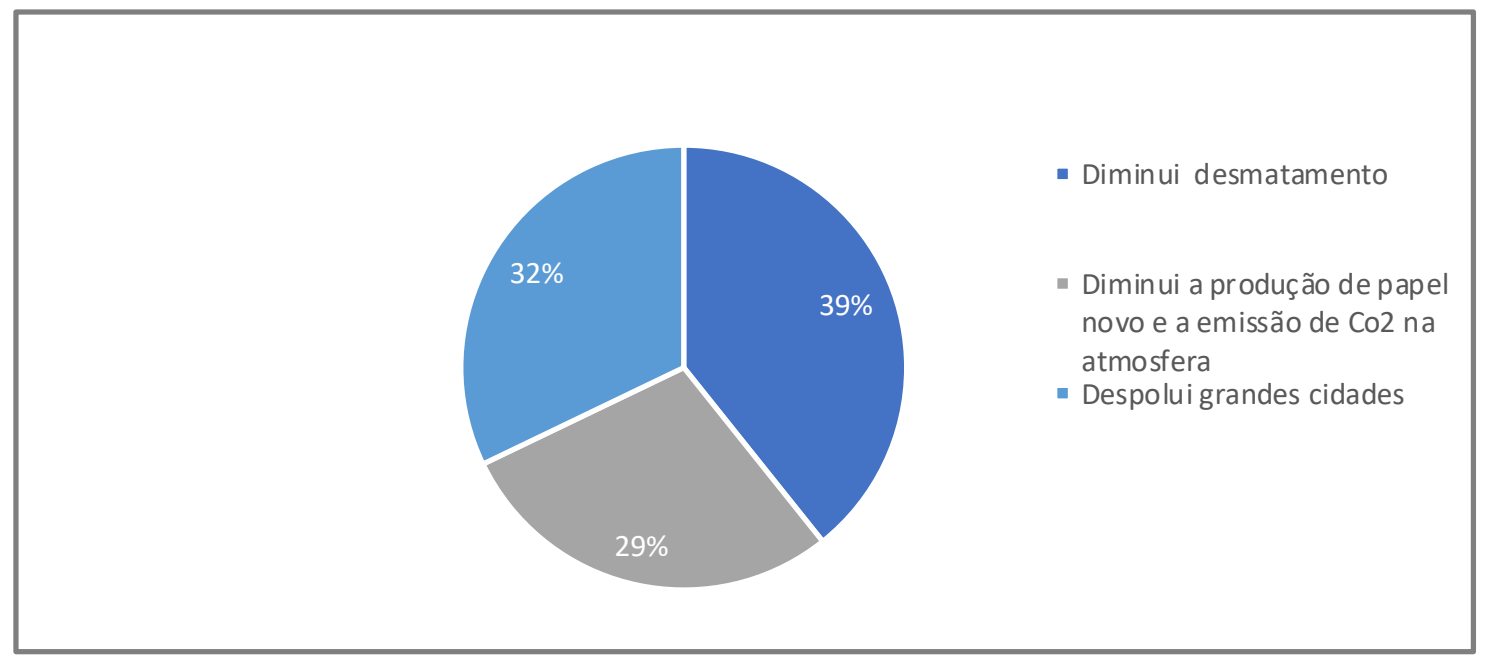

Fonte: Autores (2021).

A décima primeira questão indagou aos estudantes: ao pensar em um mundo sustentável, como se percebiam contribuindo para diminuir o desperdício de papel. Nas respostas, 15 estudantes (53\%) responderam que criariam alguma tecnologia que substituísse o uso de papel, diminuindo o consumo deste produto; 9 estudantes (32\%) responderam que criariam algum tipo de campanha para orientar as pessoas em relação ao consumo responsável deste material; 3 estudantes (11\%) responderam que iriam proibir o uso de papel por instituições de ensino, órgãos públicos etc.; 1 estudante (4\%) não soube responder, conforme a Figura 11.

Figura 11. Representação gráfica das respostas dos estudantes em relação à sua contribuição para a construção de um mundo sustentável.

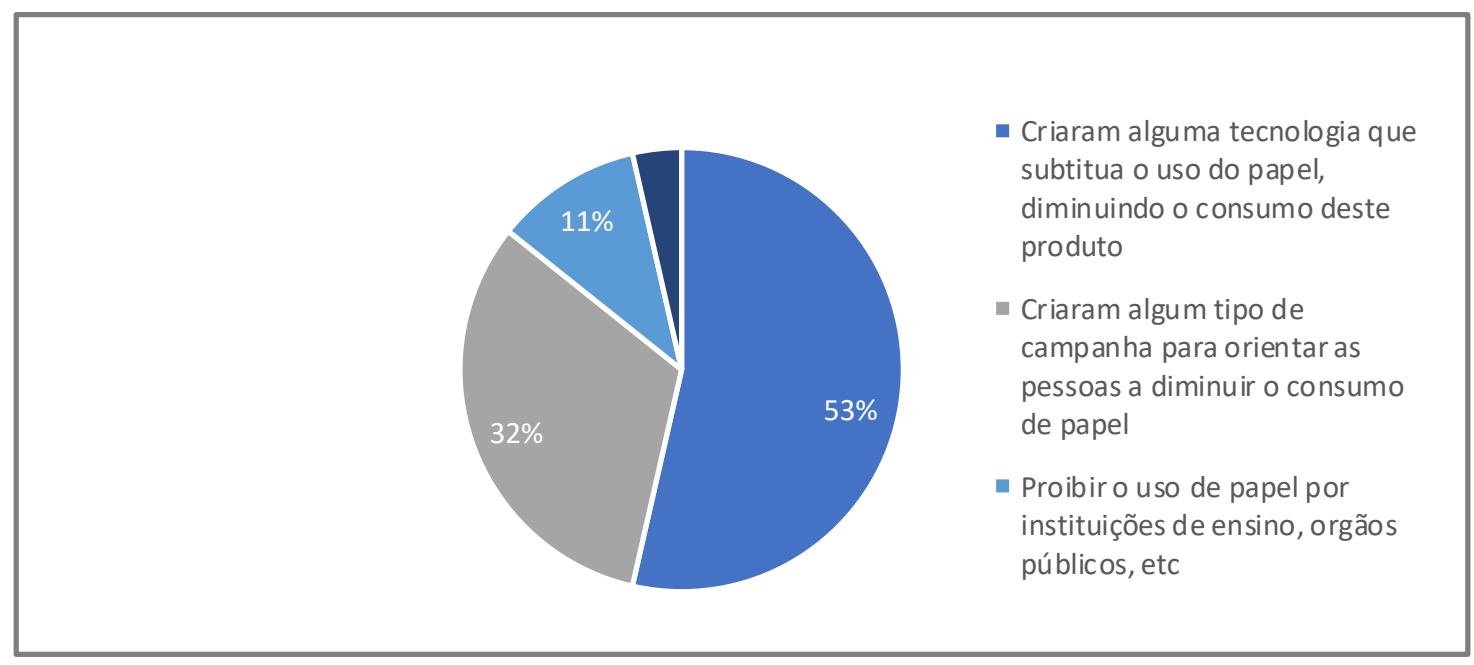

Fonte: Autores (2021).

A décima segunda questão indagou aos estudantes acerca da compreensão deles sobre a relação entre interdisciplinaridade e educação ambiental. Nas respostas, 14 estudantes (50\%) responderam que entendiam e sabiam explicar; 
8 estudantes (29\%) responderam que entendiam o que era, mas não sabiam explicar; 6estudante (21\%) respondeu que não sabia, de acordo com a Figura 12.

Figura 12. Representação gráfica das respostas dos participantes sobre a compreensão entre interdisciplinaridade e educação ambiental.

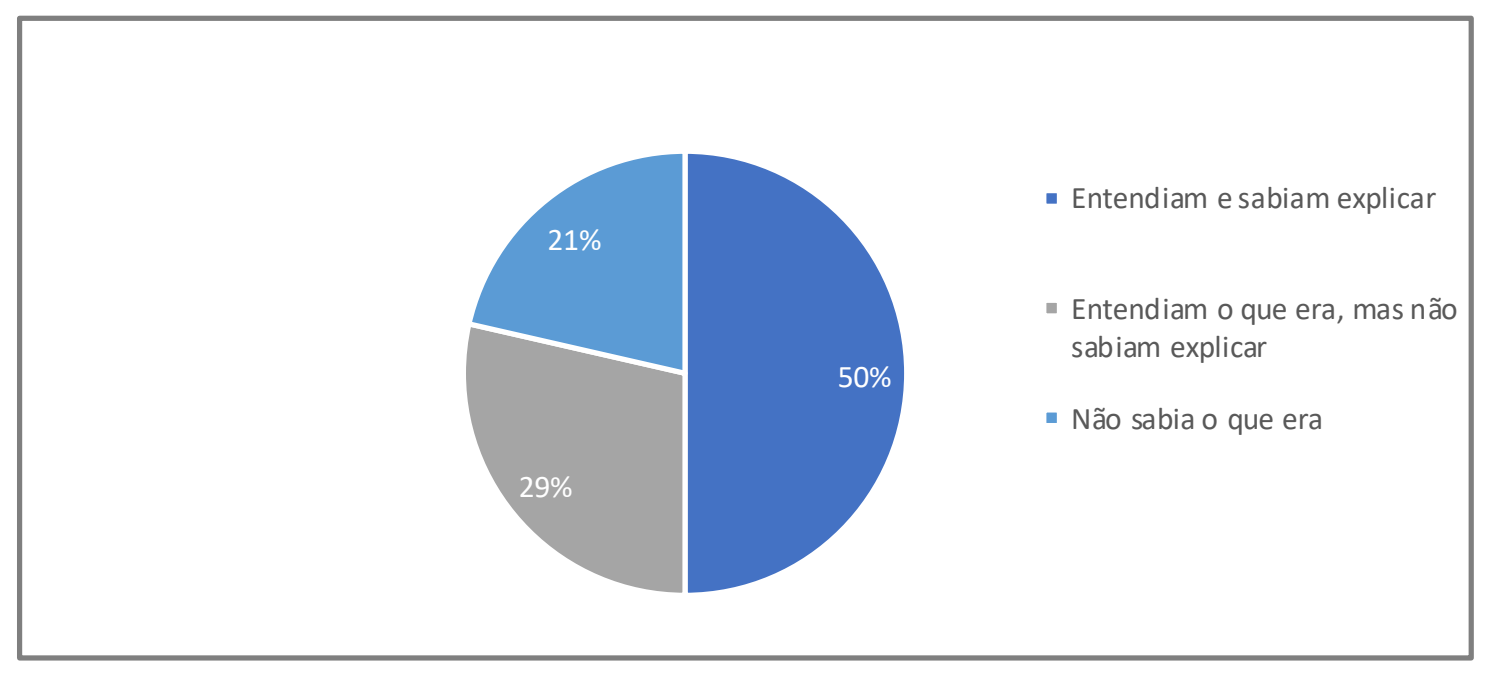

Fonte: Autores (2021).

Neste sentido, vale ressaltar que o direito ao desenvolvimento pressupõe o respeito aos princípios ecológicos, pois o ser humano, além de ser parte integrante da natureza, não é apenas um ser de materialidade física, mas também composto por um complexo sistema biológico interno que prescinde intimamente do ecossistema para subsistir e, sendo assim, os recursos materiais da natureza, limitados, que devem assegurar às pessoas a satisfação de suas necessidades básicas, necessitam de políticas de preservação.

O século 21 traz uma educação ambiental que rompe com o modelo convencional, das ações conservacionistas, colocando a transformação social na frente dos debates; transformar a sociedade é a melhor maneira de garantir a preservação e sustentabilidade da natureza (Queiroz et al. 2016). A Educação Ambiental deve ser trabalhada de forma interdisciplinar, com a utilização de conhecimentos ambientais de literatura e junto com dados do cotidiano, procurando situações que favoreçam ações ambientais e estimulem as situações de aprendizagem que resultem em uma sociedade sustentável (Zan et al. 2012).

Acredita-se que a Educação Ambiental se apresenta como uma aliada para o despertar da consciência ambiental, colaborando para que as pessoas modifiquem seus hábitos errôneos e adquiram novos valores ecológicos na redução da degradação ambiental, melhorando a qualidade de vida.

A experiência vivenciada durante a realização do projeto remeteu-nos às palavras de Roitman (2007), ao chamar atenção para o fato de que em nossos dias, a educação em ciência tem como desafio a formação de profissionais para uma sociedade em mutação, o que requer, cada vez mais, compromissos sociais, éticos e uma abordagem interdisciplinar. Sendo assim, há que se pensar em estratégias de educação que promovam um esforço no sentido de estimular o desenvolvimento da criatividade no ensino de ciências da natureza, bem como a interação horizontal entre as diferentes áreas do saber. Então, acredita-se que os estudantes que participaram das atividades propostas pelo projeto, além de conseguirem formar, aprimorar seus conhecimentos em Educação Ambiental e estabelecer a relação desses conhecimentos em mais de um componente disciplinar, iniciaram um importante processo de educação cientifica dentro da proposta estabelecida. 


\section{Considerações Finais}

Aponta-se que a discussão acerca da relação entre educação ambiental e interdisciplinaridade requer mais atenção e, principalmente, mudança de atitude da parte daqueles que compõem o contexto escolar. O presente estudo demonstrou que a adesão do corpo discente em trabalhar as questões ambientais na perspectiva interdisciplinar foi maior do que a observada por parte do corpo docente.

Buscando responder ao objetivo proposto na pesquisa, constatou-se que os participantes da pesquisa demonstraram interesse em tornar as ações vivenciadas no processo de intervenção em um projeto com atuações efetivas e eficazes, por intermédio de atitudes interdisciplinares e, desta forma conseguir o engajamento máximo de adeptos entre o corpo discente, docente e administrativo da escola.

Portanto, elucida-se que, por se tratar de uma temática ampla e complexa, os questionamentos originados não se encerram aqui. Contudo, espera-se que os resultados desta pesquisa possam servir de parâmetro e motivação para que novos achados possam vir a contribuir para a construção e produção de conhecimento acerca da abordagem da educação ambiental como proposta interdisciplinar a ser realizada no âmbito da escola.

\section{Referências}

Barcelos, Valdo H. L. (1996). A questão ambiental e a educação: um diálogo necessário. Revista do Centro de Educação, 21(1), 5-21. Brasil. Constituição Federal. Edição Especial, Serviço de Biblioteca no Lar, Encyclopedia Britanica do Brasil. Brasília.

Brasil (1999). Lei Federal n 9.795, de 27 de abril de 1999. Dispõe sobre a educação ambiental, institui a Política Nacional de Educação Ambiental e dá outras providências. http://www.planalto.gov.br/ccivil_03/leis/19795.htm.

Deslandes, S. F., \& Gomes, R., \& Minayo, M. C. S. (org.), (2013). Pesquisa social: teoria, método e criatividade. Vozes.

Farnesi, Claudia C. (1999). A realidade da Educação Ambiental nas Escolas Públicas e Privadas de Uberlândia: o trabalho dos professores. Monografia de Bacharelado em Ciências Biológicas, Universidade Federal de Uberlândia. Uberlândia.

Gomes, A. M. S., \& Ghedin, E. (2013). A Mobilização de Processos Cognitivos no Percurso Formativo de Estudantes do Mestrado Acadêmico em Educação em Ciências na Amazônia. Dissertação de Mestrado. Mestrado Acadêmico em Educação em Ciências na Amazônia. Universidade do Estado do Amazonas UEA.

Ghedin, E. \& Franco, M. A. S. (2008). Questões de Método na Construção da Pesquisa em Educação. Cortez.

Lei de Diretrizes e Bases da Educação Nacional - LDB. (2020). (4a ed.), Senado Federal, Coordenação de Edições Técnicas. https://www2.senado.leg.br/bdsf/bitstream/handle/id/572694/Lei_diretrizes_bases_4ed.pdf?sequence=1\&isAllowed=y.

Costa, C. A., \& Loureiro, C. F. (2017). A Interdisciplinaridade em Paulo Freire: aproximações político-pedagógicas para a educação ambiental crítica. R. Katál., Florianópolis, 20(1), 111-121.

Miranda, F. H. F., \& Miranda, J. A., \& Ravaglia, R. (2010). Abordagem Interdisciplinar em Educação Ambiental. Revista Práxis, Ano II, nº 4 , 2010.

Oliveira, E. C., et al. (2012). Projeto Pedagógico do Curso de Licenciatura em Ciências Biológicas. Coordenação do Curso de Ciências Biológicas, Instituto de Ciências Biológicas - Universidade Federal do Amazonas.

Oliveira, T. P. D., \& Silveira, G. T. R. (2014). Educação Ambiental na Escola: se é possível evitar, por que desperdiçar? Revista de Educação Ambiental, $19(2)$.

Queiroz, T. L. S. et al., (2016). Uma Proposta Interdisciplinar de Educação Ambiental a partir do Tema Água. Revista Brasileira de Extensão Universitária, $7(1), 15-22$

Roitman, I. (2007). Educação Científica: quanto mais cedo melhor. Brasília: Rede de Informação Tecnológica Latino Americana, RITLA. $<$ http://www.anpg.org.br>.

Rossini, C. M. \& Cenci, D. R. (2020). Interdisciplinaridade e Educação Ambiental: um diálogo sustentável. Revista Prática Docente, 5(3), 1733-1746. 10.23926/RPD.2526-2149.2020.v5.n3.p1733-1746.id830. http://periodicos.cfs.ifmt.edu.br/periodicos/index.php/rpd/article/view/830.

Silva, E. A. et al. (2014). Educação Ambiental Voltada para a Reutilização e Reciclagem dos Resíduos Sólidos no Ambiente Escolar: um estudo de caso no ensino fundamental em Recife (PE). Revista Brasileira de Educação Ambiental - Revbea. 9(2): 412-423.

Sorrentino, M., \& Trajber, R. (2007). Políticas de Educação Ambiental do Órgão Gestor. In Mello, S. S. \& Sorrentino, M. (Coord.), Vamos Cuidar do Brasil: conceitos e práticas em educação ambiental na escola - Ministério da Educação, Coordenação Geral de Educação Ambiental, Departamento de Educação Ambiental. UNESCO. 
Research, Society and Development, v. 10, n. 13, e08101320760, 2021

(CC BY 4.0) | ISSN 2525-3409 | DOI: http://dx.doi.org/10.33448/rsd-v10i13.20760

Tavares, R. B. F., \& Sousa, F. C. F., \& Santos, V. E. S. (2018). A educação ambiental com perspectiva transdisciplinar no contexto da legislação brasileira. Research, Society and Development, 7(12), 1-22, e2712478, 2018.

Triviños, N. S. A. (2009). Introdução à Pesquisa em Ciências Sociais: a pesquisa qualitativa em educação. Atlas S. A.

Zan, et al. (2012). Ensino Interdisciplinar Da Educação Ambiental Nas Disciplinas De Biologia E Química Do Ensino Médio: Uma Proposta Para As Escolas Públicas Do Município De Ariquemes, Rondônia, Brasil. Monografias Ambientais, REMOA/UFSM, (7), 1630 - 1645. 